\title{
14
}

\section{Robert O'Neill's Institutional Leadership: The End of the Cold War and the Re-emergence of a Global World Order}

\author{
John Hillen
}

International affairs are influenced by many factors, not the least of them Harold McMillan's warning, 'events, dear boy, events'. Statesmen, political leaders, military commanders, theorists, and influential writers on the topic play their role in the unfolding shape of the international arena. So too institutions - empires, states, militaries, government ministries, universities at times, international organisations, sub-state organisations, religious groups, and other popular movements - might all wield a geopolitical agenda and purpose that forms and sculpts history. But the role of the private institution - the so-called think tank — is a relatively new phenomenon, perhaps some 60-70 years old

The role of the private research institution in helping shape international affairs, rather than simply analysing their passing after the facts, is less well known. However, when one turns to look at the career of Robert (Bob) O'Neill AO, and considers his decade at the helm, as Director and then Chairman of the International Institute for Strategic Studies (IISS), one can see how a think tank - and its leader - can play a very outsized role in actually determining 
global affairs; or, at the very least, laying the intellectual and policy groundwork for tremendous shifts in geopolitics, and by doing so, helping these shifts come about.

During the time that Bob O'Neill was Director of IISS (1982-1987) he uniquely positioned the institute to accommodate a reasoned but passionate set of debates and deliberations about a very different grand strategy pursued by President Ronald Reagan and the United States - strategic questions that were at the time driving the European members of the Atlantic Alliance and some in the US further and further apart. O'Neill did not let the institute become fractured by this challenge, but rather led IISS to make intellectual space for fairly examining the new elements of Reagan's strategy and US actions, even while subjecting them to rigorous strategic analysis. His leadership paid dividends, keeping IISS not only relevant but, indeed, still central to questions of superpower rivalry and potential nuclear conflict; the Reagan grand strategy was able to unfold to good effect - pushed, questioned, and shaped by the work of IISS.

At almost the same time, recognising the likely erosion of the criticality of the institute's founding raison d'etre (managing the nuclear balance between rival superpowers), O'Neill also positioned IISS for influence and access elsewhere in the strategic world - displaying the foresight to anticipate a more multipolar world in the near future. He expanded and built the institute's finances, research agenda, membership base, and governance structure to make the narrowly focused Atlantic Alliance think tank become the most influential and truly global public policy research institute in international affairs. Any one of these feats would have been notable, but to do both in tandem sets the bar for visionary institutional leadership and influence.

By the end of his tenure as director, the IISS research agenda, conference schedules, complexion of IISS membership, and governance were all changing to encompass much of the strategic world that did not represent only the competition between US and Soviet blocs of influence. In his term as Chairman of the IISS Council (1996-2001), O'Neill expanded on this diversification of IISS's traditional NATObased and nuclear issues-oriented membership, research expertise, and convening authority. Working with the director at the time, $\mathrm{O}^{\prime} \mathrm{Neill}$ helped create the para-diplomatic regional dialogues in Asia 
and the Middle East for which IISS is so well known today, and made the institute the preeminent global strategic research institutes of its time.

However, in 1982, when Bob O'Neill arrived to take over IISS, none of that was assured, let alone in the cards. It would be a formidable leadership challenge just to keep the institute from being riven by the strategic upheavals of that time.

\section{IISS and the Advent of the Reagan Doctrine}

Sir Michael Howard, one of IISS's founders, has described the purpose of the institute at its inception and the events that led to its founding. ${ }^{1}$ IISS would study the military problems and strategies of the world - especially those the nuclear age, exclusively a European issue at the time of IISS's founding in 1958. The institute's quarterly journal was tellingly named Survival, and its premier research publication, The Military Balance, was the indispensable public accounting of the world's military forces. The philosophical heritage of the institution was hard-headed and realistic (they knew disarmament was impractical), but the research agenda was ultimately interested in avoiding war especially nuclear war. For the 24 years between IISS's founding and the arrival of Australian infantry veteran Bob O'Neill as its director, it was one of the world's preeminent research institutions that had global membership, but a Western European outlook on issues of the nuclear arms race, strategies of deterrence, and superpower rivalry.

The rise to power of President Ronald Reagan in 1980-1981 posed a challenge to the intelligent, hotly debated, but likely near-consensus among IISS members in 1980 about the suitability of the various permutations of détente tried by all American administrations since Eisenhower. President Reagan promised the end of détente and a strategy of confrontation. His predecessor, Jimmy Carter, had offered a softer version of détente than his predecessors, saying in 1977 that the US should be 'free of that inordinate fear of communism'. ${ }^{2}$

1 Howard, Michael (2006) Captain Professor: A Life in War and Peace, London: Continuum, pp. 153-65.

2 Carter, Jimmy (1977) Speech at Notre Dame University, University of South California Santa-Barbara American Presidency project records, 21 May. 
Reagan accused Carter of accommodating the Soviet Union's worst behaviours and resisting the connection between Marxist and communist movements around the world and the USSR. Mainstream Republicans did not escape Reagan's criticisms. His conservative allies, a political insurgency of sorts within the Republican Party, made much of President Ford declaring in a debate with Carter that Eastern Europe was not under Soviet domination and insisting in the follow up that Poland, Romania, and Yugoslavia were free from Soviet interference.

The impression of weakness inherent in Carter's version of détente, exacerbated by the Soviet invasion of Afghanistan and the taking of American hostages in Iran in 1979, doomed Carter's re-election chances in the opinion of many historians. In 1980, Ronald Reagan stormed to a huge victory over President Carter, promising to return America to strength and greatness again — in large part by vigorously resisting the USSR, Soviet-inspired movements, and supporting anticommunist movements the world over. Reagan noted:

As the foundation of my foreign policy, I decided we had to send as powerful a message as we could to the Russians that we weren't going to stand by anymore while they armed and financed terrorists and subverted democratic governments. Our policy was to be one based on strength and realism. I wanted peace through strength, not peace through a piece of paper. ${ }^{3}$

To an institution such as IISS, enjoying a highly intelligent and now somewhat rehearsed existence as a centre of strategic thinking about arms control, the nuclear balance, and theories of deterrence, this aggressive rhetoric and the implicit Reagan policy of confrontation was a challenge to absorb. As IISS veteran Sir Lawrence Freedman has written:

The status of the Institute depended on its ability to pay attention to its core business, which had always been focused on transatlantic relations and the conduct of the Cold War. The context was a sharp discontinuity in American policy. During the 1970s the Institute had worked naturally within the mainstream transatlantic consensus, which was focused on the appropriate mix of détente and defence, which led to a concentration on the conduct of arms control.

3 Reagan, Ronald (1990) An American Life: The Autobiography, Kindle edition, New York: Simon \& Schuster, loc. 3778-80. 
Yet during the Jimmy Carter years (in which many IISS alumni served) this consensus began to be challenged. Key figures in the membership were taking an increasingly sceptical view of both Soviet intentions and in consequence the role of arms control and the durability of deterrence (notably Albert Wohlstetter among the senior figures and Colin Gray, who was briefly on the staff, among the Young Turks). The debate became increasingly polarised, and by the early 1980s this polarisation had spread to transatlantic relations. In Ronald Reagan's Washington the new mainstream view was to doubt Soviet motives, question the value of arms control and prepare for a period of intensive arms racing. Only Margaret Thatcher's government showed any sympathy, yet even in Britain the official line remained pro-détente and pro-deterrence.

This created real political difficulties for IISS. It needed to work with the US government, which was wary of consorting with organisations which were perceived to be promoting erroneous visions, and the major charitable foundations, which were often more attached to the policies of the 1970s and who saw their role as being to challenge and rein in the provocations of the Reaganauts. On the streets there was an increasingly vocal movement protesting against nuclear weapons and claiming that official policies were propelling the world to disaster. There were many pitfalls in this situation for an international institute, which had to be sensitive to the political and intellectual currents in a range of countries if it was to satisfy an increasingly diverse membership, without losing its way and purpose. ${ }^{4}$

The first few years of the Reagan Administration did not do much to settle nerves or smooth over varying opinion, and a National Intelligence Council report of the time acknowledged, with understatement, substantial 'differences between the United States and our West European allies'. ${ }^{5}$ By 1982, as O'Neill was being recruited to be IISS's first non-European Director of the IISS, Cold War tensions were at their height as the American administration drove hard to reverse what it saw as Soviet ascendency and American decline. Reagan's new Secretary of State George Schultz described the attitude of the administration and conflict with Europe thusly:

4 Freedman, Lawrence (2006) 'Bob O'Neill and The Art of Academic Leadership', Australian Journal of International Affairs 60(1), pp. 13-17.

5 Brands, Hal (2014) What Good Is Grand Strategy?: Power and Purpose in American Statecraft from Harry S. Truman to George W. Bush, Ithaca: Cornell University Press, p. 115. 
Throughout the cold war era, America's responsibilities as a superpower had been fulfilled with impressive success. But fear of flagging will or failure had become pervasive. The American presidency had become a story of successive agonies: the assassination of John F. Kennedy; the anguished departure of Lyndon Johnson at the nadir of the Vietnam War; Richard Nixon's de facto impeachment; Gerald Ford's healing but brief stewardship; and Jimmy Carter's miseries, which, with a weak smile, he spread across the American and international scene. In June 1980, I had said in a speech to the Business Roundtable, 'All around us, and plain for all the world to see, is confusion about our aims, deterioration in our world position, and deep concern, perhaps fear, that we are no longer able to establish a tough-minded sense of direction and stick to it.' Now, in mid-1982, we were still besieged by problems and buffeted by events. Ronald Reagan's program, off to a strong start at home, was struggling abroad. President Reagan had set out to restore America's strength, optimism, and 'can do' spirit. He was strengthening our defence capabilities, invigorating the morale of our men and women in uniform, and carrying the message of political and economic freedom around the world. But the president's foreign policy refused to lift off and soar. I felt the United States held the winning hand, but it was proving a difficult hand to play. Bitterness marked the discord between the United States and our European allies over the proposed construction of a gigantic 3,500-mile pipeline running from Siberia through rugged terrain to carry gas, Soviet gas, into Europe. The American and European economies were in a recession, and the pipeline contract meant good jobs during a time when they were hard to get. ${ }^{6}$

Yet the upcoming year, 1983, would be critical for nuclear arms negotiations: close U.S.-European coordination would be essential. New Soviet missiles, SS-20s, had been deployed and, since the 1970s, explicitly and directly targeted on Europe. These intermediate-range missiles could not reach the United States. Their purpose was to intimidate West Europeans as part of an ongoing Soviet effort to drive a wedge between the United States and our NATO allies. U.S. missiles, as agreed by all NATO members, were scheduled to be deployed beginning in late 1983 on European soil as a counter to these Soviet deployments. Crucial negotiations would determine whether the arms race would be speeded up or scaled back. The pressing need for coherence and unity in the alliance would be practically impossible to manage, I knew, unless we could dissipate the acrimonious atmosphere

6 Shultz, George P. (2010) Turmoil and Triumph: My Years as Secretary of State, Kindle edition, New York: Scribner, loc. 128-35. 
with the Europeans created by the pipeline dispute. U.S.-Soviet relations had gone into the deep freeze when the Soviets invaded Afghanistan just after Christmas of 1979. Now the Soviet-backed crackdown in Poland further deepened the cold. Relations between the two superpowers were not simply bad; they were virtually non-existent. West German Chancellor Helmut Schmidt said to me in May 1982, 'The superpowers are not in touch with each other's reality. The Soviets can't read you. More human contact is needed.' 'The Soviet system is incompetent and cannot survive,' I had said in a speech at Stanford in 1979. 'In the struggle with communism freedom is the ideological victor in the world.' Now, three years later, in 1982, I had not changed my mind. The Soviets had to be made to realise that they could not succeed with aggression, nor could they win an arms race. But we did not want to spark conflict through fear or miss opportunities to resolve outstanding problems. President Reagan recognised the Soviet Union for what it was: aggressive, repressive, and economically bankrupt, but militarily powerful, with an arsenal of strategic nuclear weapons able to devastate us in thirty minutes. We must recognise that reality, I knew, but we should also be ready to deal with the Soviets more constructively if the opportunity arose. We had to gather support for this approach: from Congress, the press, and the public. Global stability depended on how we dealt with the Soviets. ${ }^{7}$

It was into this cauldron that Bob O'Neill was thrown in 1982 plucked out of the antipodes and moved to the centre of the Cold War as director of the preeminent European think tank, studying its nuclear and military ramifications. His appointment was not unanimously supported, some perhaps thinking that if the aggressiveness of the Reagan doctrine threatened to riven the European-based membership, then it would take an insider to prevent such an outcome. But, O'Neill had notable bonafides as a Cold War scholar and strategist, ${ }^{8}$ and he would need those to cement his position as a determined director, even while preparing to change and expand the focus of the institute to other military and strategic matters.

7 Ibid., loc. $148-54$.

8 Bob was the editor or co-editor of a number of books on nuclear arms and Cold War strategy issues, including O'Neill (ed.) (1974) The Strategic Nuclear Balance: An Australian Perspective, Canberra: Strategic and Defence Studies Centre, The Australian National University; and O'Neill, Robert and David Schwartz (eds) (1987) Hedley Bull on Arms Control, London: Palgrave Macmillan. 
$\mathrm{O}^{\prime}$ Neill inherited an IISS membership that was largely resistant to the Reagan administration approach, which contrasted sharply to the carefully created strategic, military, and technical framework of détente that IISS had been a key player in constructing over the past decades. Even so, in the institute's research agenda and conference presentations, $\mathrm{O}^{\prime} \mathrm{Neill}$ made space for a rigorous and serious discussion of the new and highly controversial American strategy that was two years underway when he took charge. Too smart a leader to ever show anything but an even hand (to this day, I don't know how Bob really felt about it in his strategic heart at the time), he prepared the way for discussions that were scrupulously fair, and by doing so, the institute was able to show more openness to the new American strategy than others did at the time. ${ }^{9}$

It cannot be stressed how different the Reagan approach was to the consensus of the time. Reagan described his thinking in his autobiography. It was not considered a sophisticated view - especially by foreign policy sophisticates.

The Soviet Union we faced during my first winter in office was guided by a policy of immoral and unbridled expansionism. During that first year, we embarked on a broad program of military renewal to upgrade our land, sea, and air forces and adopted a foreign policy aimed at making it clear to the Soviets that we now viewed them through a prism of reality: We knew what they were up to, we were not going to accept subversion of democratic governments, and we would never accept second place in the arms race. At the same time, recognising the futility of the arms race and the hair-trigger risk of annihilation it posed to the world, I tried to send signals to Moscow indicating we were prepared to negotiate a winding down of the arms race if the Soviets were also sincere about it - and proved it with deeds. These policies were linked: Because we now viewed the Soviets through the prism of reality, we knew we would never get anywhere with them

9 Bob later became a forceful and leading voice for the abolition of nuclear weapons on the Canberra Commission of 2006, so I don't think he'll ever be accused of being overly sympathetic to the hard line of Reagan's policies. But he was scrupulously fair. Ironically, Reagan made much of his own nuclear weapon abolitionist ambitions, including to Gorbachev during their first meetings. See Lettow, Paul (2006) Ronald Reagan and His Quest to Abolish Nuclear Weapons, New York: Random House. 
at the arms control table if we went there in a position of military inferiority; if we were going to get them to sue for peace, we had to do it from a position of strength. ${ }^{10}$

The European-led near-consensus reflected in most IISS work at the time $^{11}$ maintained that the American position was strong enough and improving it military or technologically would only upset the balance of power that the institute had so carefully analysed. O'Neill noted in his 1984 conference summary that IISS member Albert Carnesale 'summed up the European argument thus: "Western Europe objects to any change in a security system that seems to be working well enough as it is, therefore the burden of proof is on those who propose change."'12

However, fundamental to accepting the legitimacy of Reagan strategy and providing the beginnings of such 'a burden of proof' was that one had to accept that the Soviet Union had been measurably in the military ascendancy during the 1970's. As Hal Brands has written:

Reagan was prepared to enter into arms-control negotiations on these and other weapons, but in the meantime he deemed it imperative to restore the leverage that came with military power. 'A sound EastWest military balance is absolutely essential,' he stated; strength was the indispensable precondition to everything Reagan hoped to do. ${ }^{13}$

IISS, of course, was the premier independent measuring stick of the balance of military power. With the deployment of Soviet SS-20 missiles in Europe in the early 1980s, and the USSR's involvement in conflicts from Central America through to Afghanistan, that might not be so hard to prove in theory - but the Reagan response to it still powerfully challenged the mainstream consensus. For the most part, IISS members could live with the current balance of power as being balance. O'Neill, in guiding the work, research agenda, membership

10 Reagan, Ronald (1990) An American Life: The Autobiography, Kindle edition, New York: Simon \& Schuster, loc. 7998-8006.

11 There has never been a true consensus on any issue in IISS - made up as it is of individual staff researchers and thousands of members. But on the nuclear balance question, détente, and deterrence, there was - as Lawrence Freedman referred to - as close to near-consensus as IISS members could get when compared with the Reagan approach.

12 O'Neill, Robert (1985) 'Conference Report', in New Technology and Western Security Policy, Part III: Papers from the IISS 26th Annual Conference in 1984, Adelphi Paper 189, London: IISS. 13 Brands, Hal (2014) What Good Is Grand Strategy?: Power and Purpose in American Statecraft from Harry S. Truman to George W. Bush, Ithaca: Cornell University Press, p. 111. 
contributions, and conferences of the institute that would address the Reagan strategy, did not give voice to the idea that Reagan and Shultz were crying wolf or over-inflating Soviet ascendancy for political purposes (although many in Europe thought exactly that). As $\mathrm{O}^{\prime} \mathrm{Neill}$ noted at the 1983 annual conference in his report: 'Whatever their political significance, Soviet advances are real and, from an American perspective, the "balance" had altered unfavourably. Should the United States aim at superiority and not merely maintenance of parity remains the most important, albeit unresolved question. ${ }^{\prime 14}$

Overall, and perhaps due to his strategic upbringing on the other side of the world, O'Neill exhibited more scholarly detachment from the transatlantic consensus and therefore ended up, in retrospect, appearing to enjoy more foresight or open-mindedness than most IISS experts or conferees in these mid-1980s gatherings. Summing up the attitude of annual conferees in 1983, O'Neill wrote: 'Little optimism was felt in the committee for the possibility of inducing change in Eastern Europe. At best the fruits for such Western policies (i.e. Reagan pressure) would be marginal although, of course, over a long time, the margins would accumulate.' Still, O'Neill opened the door to the Reagan line and its proponents, noting in the same proceedings:

Yet the future may hold revolutionary changes in and for Eastern Europe rather than evolutionary ones. The Soviet Union's likely response to such changes is essentially unpredictable. She might simply muddle through or down, sensing inevitable decline in her empire she might consider alternatives. ${ }^{15}$

Although the IISS debates were heated at the time, and definitely unsettled well into the late 1980s, O'Neill's even-handed approach made space for the Reagan strategy to be examined seriously, and for IISS to be used as a critical sounding board. I see no evidence that the majority of the members, especially those European members who came of age forging the transatlantic mainstream consensus that Reagan so powerfully challenged, were ever convinced that the Reagan approach would be anything but disruptive to a well-thought out strategic near-consensus about how to resist Soviet aggression

14 O'Neill, Robert (1984) 'Conference Report', in The Conduct of East-West Relations in the 1980s, Part III: Papers from the IISS 25th Annual Conference in 1983, Adelphi Paper 189, London: International Institute for Strategic Studies.

15 Ibid. 
without the confrontation Reagan appeared to promise. But, in the end, $\mathrm{O}^{\prime}$ Neill's approach allowed for the institute's analysis and work to be part of what was indeed a coherent, if controversial, grand strategy from the administration - and one that ultimately was successful. As Hal Brand's recent archival examination of the administration has shown:

These sources (NSC documents from the early 1980s) illustrate that there was a Reagan grand strategy - a comprehensive, long-term vision for U.S. policy toward Moscow. This strategy drew heavily on Reagan's own ideas and involvement, and utilized all elements of national power. It was premised on the idea that the Soviet Union was far weaker than it had looked in the late 1970s, and that the United States could take advantage of that weakness by exerting pressure in the military, economic, political, and ideological realms. This was the unifying rationale behind the major elements of Reagan's statecraft, from his enormous military buildup, to his eponymous doctrine of supporting anti-Soviet insurgents in the Third World, to his strident rhetorical condemnations of Moscow and other measures. The primary goal of these initiatives was not to force the collapse of the Soviet Union (as some hard-liners advocated), but to provide diplomatic leverage that could be used to moderate Soviet behavior and reduce Cold War tensions on terms favorable to the United States. In essence, Reagan's grand strategy - spelled out in presidential decision directives issued in 1982 and 1983 - was meant to capitalize on America's competitive advantages vis-à-vis Moscow, to reverse the tide of the Cold War, and then to begin the process of forging a more stable superpower relationship. ${ }^{16}$

\section{SDI and IISS}

The Reagan military build up, especially the deployment of Pershing intermediaterange nuclear missilesin Western Europe, was controversial in IISS and the world over, but the administration's Strategic Defense Initiative (SDI) elicited even more emotion and aggravation among those who thought the nuclear balance was carefully and responsibly

\footnotetext{
16 See Brands, Hal (2014) What Good Is Grand Strategy?: Power and Purpose in American Statecraft from Harry S. Truman to George W. Bush, Ithaca: Cornell University Press, p. 103. I view this work as one of the few neutral treatments of Reagan's strategy and the end of the Cold War, positioned as it is between the hagiographies by Reagan's allies and the still spiteful analysis of his critics, who cannot bring themselves to acknowledge even a slight contribution of his strategy to the peaceful end of the Cold War.
} 
understood by both super powers. SDI was as important to Reagan's strategy as it was disruptive to the nuclear balance consensus. Reagan later wrote: 'some people may take a different view, but if I had to choose the single most important reason, on the United States' side, for the historic breakthroughs that were to occur during the next five years in the quest for peace and a better relationship with the Soviet Union, I would say it was the Strategic Defense Initiative, along with the overall modernisation of our military forces'. ${ }^{17}$

However, in 1983-1984, even the perception of a technological advantage on one side of the Cold War, which could upend several decades of game theory and nuclear strategy, was an overwhelmingly unwelcome development for those who had built the existing transatlantic nuclear consensus. Many, including much of the IISS membership, channelled their disapproval into scepticism about the technological potential itself. Bob O'Neill took the issue head on neither promoting the technology or the strategic changes it might portend, but also not resisting a mature discussion of its potentiality. It was no mean feat to walk this political tightrope. As Lawrence Freedman recalled:

To some extent coming from Australia helped Bob establish his authority as Director of IISS. This nationality carried paid-up membership of the Western alliance but a degree of distance from the immediate transatlantic rows. Yet his effectiveness went beyond nationality, or even his natural diplomatic skills, to an understanding of the role of the Institute as a forum for debate and research. This was different to the stance taken during the IISS's pioneering years of the 1960s when it failed to address in its publications the most divisive issue of the time, the continuing war in Vietnam. A good example of Bob's approach, with which I happened to get involved, was the response to President Reagan's strategic defense initiative (SDI), better known as 'star wars', which as widely seen to be both foolhardy and provocative. Rather than refuse to take the issue seriously, which was for a time the inclination of European governments, Bob raised the money for an extensive, almost smothering program, of analysis, which eventually came to be published in a series of Adelphi Papers. Some of these contributed to moving the debate along, addressing the technical questions of missile defences as well as the more overtly

17 Reagan, Ronald (1990) An American Life: The Autobiography, Kindle edition, New York: Simon \& Schuster, loc. 7994-7. 
political and doctrinal. By the time this program was complete (which was never the case with the SDI itself) the world had moved on and East/West relations were moving into a more constructive phase. The key point was that nobody felt excluded, the important issues had been ventilated and the credibility of the Institute as a forum where these matters were addressed was enhanced. At the 1984 annual conference, for example, American policy-makers first began to engage with the anxieties of their allies over the implications of this particular policy. ${ }^{18}$

Bob O'Neill's willingness to take on SDI instead of deriding it technologically and strategically, or dismissing it as fantasy unworthy of strategic consideration, as many institutes of the time did, is a good example of his subtle but strong institutional leadership. He did not take sides, but rather gave numerous perspectives their day in the sun - and subjected each to analysis and critique. In the end, this approach not only helped IISS successfully navigate the challenge to it from the Reagan doctrine and the heightened Cold War tensions when Bob became director, but kept the institute coherent enough for Bob to implement his second great example of international strategic leadership during his time as IISS Director and later Chairman.

\section{Preparing IISS for the Re-emergence of a Global World Order}

Bob O'Neill's second major institutional move was to revitalise and build the infrastructure of the institute - financial resources, information technology, research staff, publications, and membership - by expanding and revitalising the core purpose and expertise of IISS. Starting as he did in the mid-1980s, and gaining momentum as Reagan and Gorbachev began to thaw the superpower tensions of the early 1980s, Bob repositioned the institute as a truly global body — in research expertise and membership — while still focusing on military issues and problems of strategy.

18 Freedman, Lawrence (2006) 'Bob O'Neill and The Art of Academic Leadership', Australian Journal of International Affairs 60(1), pp. 13-17. 
Financially, the institute had not lived exactly hand to mouth in its first 25 years before $\mathrm{O}^{\prime}$ Neill became director, but was close to it at times. And what resources it did enjoy - research grants, publications income, and membership fees - were related to the institute's core expertise in European security, the Atlantic Alliance, the nuclear balance of power, and the superpower rivalry.

$\mathrm{O}^{\prime}$ Neill set about trying to draw in money to match a large challenge grant from the Ford Foundation that would give IISS its first true capital fund, and thereby control over the direction of its research agenda and the possibility of expanding the expertise of the institute beyond its core area. $\mathrm{O}^{\prime} \mathrm{Neill}$ succeeded in raising the funds, and hired a research staff to reinforce the expanded agenda of the institute, and build up competencies in other areas of strategy and military affairs. In particular, he raised funds from the Rockefeller Foundation for a regional security program, including an assistant director for regional security. He set about expanding the annual conference agenda, which had a long lead time (see below), but in the meantime he commissioned Adelphi Papers on Security in East Asia, the two Koreas, South African and other African security issues, and the Middle East - among other non-nuclear balance of power in Europe topics.

$\mathrm{O}^{\prime}$ Neill also set out to improve other elements of the infrastructure at IISS beyond its financial base. When he arrived at IISS there were no computers, and so information technology as an important component of public policy research was introduced by $\mathrm{O}^{\prime} \mathrm{Neill}$. He also took steps to widen the appeal and distribution of research and publications many of which had been styled in the 1960s and were not part of an updated sales and distribution network.

Knowing that ultimately he was leading a membership based organisation, O'Neill launched a drive to add more IISS members from East Asia and the Middle East. Over some objections, he pushed for Chinese members and contributions, starting in the mid-1980s. He also worked to diversify the IISS Council, which along with the Trustees of IISS was the body of foreign policy notables who acted as the governing and advisory body for the institute. Council members were added from Asia and the Arab countries of the Middle East.

One of the most telling and profound expressions of IISS focus and activity - of its leadership, research staff, and membership interests - was the annual conference. Habitually held in Europe and almost 
always focused on some aspect of the nuclear arms race or super-power rivalry, the annual conference appropriately captured the intellectual energy of IISS and its members.

Bob inherited this Euro-nuclear-superpower focus. Prior to his arrival, as part of the usual pattern, in 1978, the topic of the conference was 'Prospects of Soviet Power in the 1980s'. In 1979, the institute met in Switzerland to discuss 'The Future of Strategic Deterrence'. The 1980 annual conference in Italy marked a bit of a departure from the usual nuclear balance issues, looking at conflict in the Third World, but through the lens of super power rivalry. A 1981 conference in the US explored America's security. The 1982 conference in The Hague looked at 'Defense and Consensus: The Domestic Aspects of Western Security'. The 1983 annual conference, Bob's first as director, was held in Ottawa and focused on 'The Conduct of East-West Relations in the 1980s'. With annual conferences some three years in the making and planning, at this time Bob started plans to re-orient the annual conference and the institute in general. 1984 saw the institute meet in Avignon to consider 'New Technology and Western Security Policy', ${ }^{19}$ and 1985 saw the last of the classic cold war nuclear-balance IISS European conferences in Berlin, with a focus on 'Power and Policy: Doctrine, the Alliance, and Arms Control'.

In 1986, the O'Neill agenda for expanding and revitalising IISS's institutional reach and infrastructure came visibly onto the scene with the annual conference held in Kyoto, Japan, and featured many new (non-European) faces. 'East Asia, the West, and International Security' featured Henry Kissinger and speakers from Japan, China, Australia, and elsewhere. In O'Neill's summing up of that landmark conference, he departed from the standard nuclear balance language of IISS over the previous 28 years and referred to different strategic shaping factors, such as 'economic and social factors' that would 'dramatically' affect the relative standing of states and their security in Asia. He had a nuanced look at alliance structures, technology, economics, reform, 'the market revolution in China', and development

19 Read 'East-West' here in IISS patois of the time as 'Soviet Bloc-Western Bloc'. A few years later, Bob would be at pains in his 1986 conference write up to redefine 'East' for the institute as what was classically known as the Far East/Asia. 
in the region. His approach foreshadowed a more subtle geopolitical and grand strategic approach to analysis than the more scientific nuclear throw-weight formulas of the European balance of power. ${ }^{20}$

The following year IISS was back in Europe with a conference in Barcelona - but one that strategically looked south, not east across central Europe. The focus of that 1987 conference (Bob's last as director) was security in the Mediterranean and the Middle East, and featured Israeli and Arab speakers, among others. O'Neill still allowed for some committee examination of Soviet-US-Europe Cold War issues, as they were still central to global security during this time of new IISS expansion. But O'Neill's push to have IISS expand its scope of research, its intellectual aperture, and its membership perspective paid dividends, even in its historically core area of expertise. The new global perspective pushed by $\mathrm{O}^{\prime} \mathrm{Neill}$ ironically allowed the institute to perhaps to lift its focus from the nuclear balance ledger book if you will, and see more broadly the whole of the strategic enterprise and the global arena. The work on the military dimensions of the super power rivalry presented at the southern-focused Mediterranean conference proved to be prescient - or at least Bob O'Neill was able to present it that way in the proceedings. Although an unexpectedly quick and dramatic beginning-of-the-end to the Cold War was still two years away, $\mathrm{O}^{\prime}$ Neill remarked in his conference summing up that in reference to the US-Soviet conflict, 'we may well be at one of history's hinge points' ${ }^{21}$

As the Cold War ended, a few subsequent IISS conferences sensibly returned to focus on the end of the superpower rivalry, but Bob had set the stage - a world stage - for IISS, and there would be no looking back. The funding of this expansion and revitalisation, the research staffing and scholarship that bolstered it, the new scope of the membership and governance that he had put into place made it a truly global think tank, just at the time the end of the Cold War brought about a diffusion of power and strategic challenge in the world. In the mid to late 1980s not everyone could see this, and many thought IISS need not change its research and membership focus. Critics of Bob's moves claimed that IISS was not the UN, and should not expand its focus.

20 See O'Neill, Robert (1987) 'Concluding Remarks', in East Asia, The West, and International Security, Adelphi Paper 212, London: IISS.

21 O'Neill, Robert (1998) 'Conclusion' in Prospects for Security in The Mediterranean, Adelphi Paper 231, London: IISS. 
Bob's foresight was rewarded, of course, with the end of the Cold War and the rise of multiple centres of power and strategic challenge in the world. During his time as Chairman of the Council (1996-2001), many intelligent voices were doubting the relevance of militarycentred research institutes due to the sheer unlikelihood of major power conflict. ${ }^{22} \mathrm{O}^{\prime} \mathrm{Neill}$, together with energetic new Director John Chipman, conceived the idea for using the IISS's global convening power he had built as director a decade prior, in order to sponsor ministerial-level regional security conferences - starting in Asia. The marquee events on the international security calendar and of the institute are now those conferences - the Shangri-La Dialogue for Asian/Pacific security issues and the Manama Dialogue for Persian Gulf and Middle East security issues.

Institutional leadership is difficult. Especially of membership based institutes that largely operate by committee and a type of informal near-consensus. Any scholar can forcefully express an opinion in a book, a journal article, or a conference paper - coherence lends itself to individual efforts. But to lead multifaceted and complex institutions composed of thousands of opinionated members and donors in a coherent direction, all the while building and broadening the institution's infrastructure, appeal, membership, and influence, is a real feat.

For Bob O'Neill to have kept IISS as intact as he did during the challenge to the transatlantic consensus presented by the early Reagan years is something that should be recognised and saluted. It was difficult, and yet he did it elegantly. For him to not only keep the institute whole but to also accommodate a fair and rigorous treatment of the heretical strategies of the Reagan doctrine such that they could actually be improved by the analysis and debate of IISS is a marvel of leadership - both strong and subtle. And, finally, for him to simultaneously expand the institute's reach and appeal in such a way that it was ideally prepared for the multipolar world that was to emerge soon after his directorship ended was a final transcendent act of intuitional leadership at its finest.

22 See, for example, Friedman, Thomas (2005) The World is Flat, New York: Farrar, Straus and Giroux; and Fukuyama, Francis (1992) The End of History and the Last Man, New York: Free Press. A better guide to the fleeting nature of the peace dividend phenomenon is Howard, Michael (1978) War and The Liberal Conscience, New York: Columbia University Press. 
This text is taken from War, Strategy and History: Essays in Honour of Professor Robert O'Neill, edited by Daniel Marston and Tamara Leahy, published 2016 by ANU Press, The Australian National University,

Canberra, Australia. 